Jovana J. Rupar

\title{
ENCOUNTERING OTHERS ${ }^{1}$
}

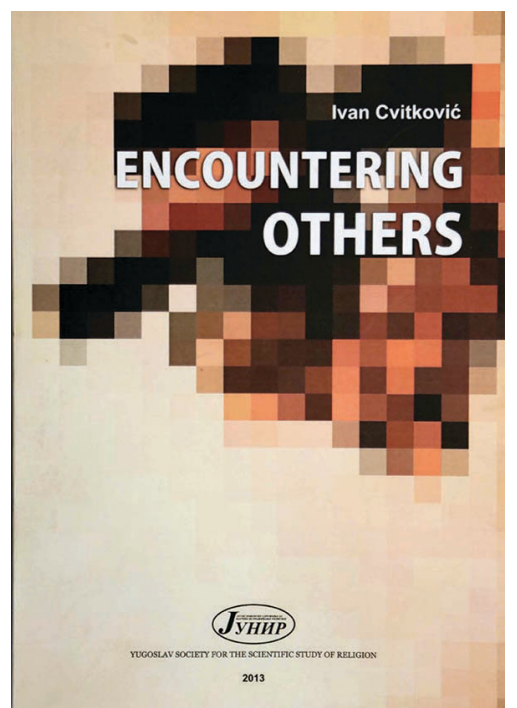

Encountering Others represents a collection of papers in English written by Ivan Cvitković, a full professor of sociology of religion at the Faculty of Political Sciences in Sarajevo. It was published in the honor of the $1700^{\text {th }}$ anniversary of the Edict of Milan and the $20^{\text {th }}$ anniversary of the annual conference of the Yugoslav Society for the Scientific Study of Religion and represents a contribution to sociological studies of religion.

The book comprises eleven papers presented at various conferences of the Yugoslav Society for the Scientific Study of Religion from 1998 to 2012. The collection is divided into two parts: Religious and Confessional Identities in Bosnia and Herzegovina and Open Questions of the Sociology of Religion. It also contains a complete six-page bibliography and a helpful name index. The papers explore a number of current topics, including relations between various religious communities in the Balkans, the relation between national and confessional identity, the impact of globalization on religious practices, the return of the religion into the public sphere on exYugoslav territories, religious practices of national minorities. The preface, written by the sociologist Dragoljub Đorđević, discusses the reasons for publishing the collection and reflects upon the life and work of Ivan Cvitković, an eminent and highly influential sociologist of religion. In the course of the following review I will look into each of the papers in greater detail.

The aim of the first paper is to look at the relation between religious teaching and the people/the nation. The author is trying to examine the attitude different religious models have towards the concept of a nation. A distinction

\footnotetext{
${ }^{1}$ Prikaz knjige Encountering Others: Religious and Confessional Identities in Bosnia and Herzegovina. Religija\&tolerancija, Novi Sad, br. 21/2014, str. 215-218.
} 
is made between universal and national religions. The author comes to the conclusion that three models of relation toward the other nations can be singled out: model of choseness, model that encourages intolerance and a model of tolerance. In the case of the Balkans, it is argued that the model of identification of religion and the nation led towards the creation of a nation on the basis of the religious principle.

The second paper gives a short overview of the concepts of national and confessional identity as two most important collective identities and furthermore, defines their mutual relationship. The major standpoints are that confessional identity can override the national and be taken as a sign according to which people define themselves; confessional identity is sociologically easier to determine and represents a more powerful factor which can divide the national identity. The rise of religious nationalism supports the author's observation that although religion and confession contribute to self-identification, they can often be misused.

As Cvitković points out, the question of the relation between Christians and Muslims in Europe is becoming more relevant mainly because of the stronger political role of Islam and the increase in the number of Muslim extremists who use religion for political and terrorist actions. Therefore, the aim of the third paper is to overview sociological-political characteristics of the situation between Christians and Muslims in the Balkans and to look into the future of their relationship. The author suggests that religions contribute to social conflicts and agrees that there is no justification for violence done in the name of religion.

Since the role of Protestantism, as one of the official state religions, on exYugoslav territory has had no significant influence, professor Cvitković feels that it would be valuable to speak about it in greater detail. By examining the relation of historically based religious communities, such as Roman-Catholic, Islamic and Jewish, toward Protestantism it seems that Cvitković is trying to underline discriminatory elements of the "Law on the Freedom of Religion and the Legal Position of the Churches and Religious Communities in B-H". The author intends not only to evaluate the nature of the relation between abovementioned communities and to give the data on the diffusion of Protestantism in Bosnia and Herzegovina but also to look into the reasons for undermining Protestantism in favor of other religions. His standpoint is stated openly and clearly - religious pluralism and religious freedom are guaranteed by the Constitution and should be respected.

The fifth paper is dedicated to religious practices of minority groups, namely Roma's religious beliefs. Professor Cvitković believes that Roma's re- 
ligion might be called a natural religion since their religion is not explicitly announced or founded. Some of the topics the author writes about, which form a part of Roma's religious tradition, are foretelling, superstitions, belief in supernatural, holidays/customs, fasting. He tries to give an answer to the question whether a notion of God exists in Roma's beliefs and what the attitude of Roma is toward the religion of other nations.

The next paper attempts to present the author's observations on the nature of religious identity at the border, which the author defines as a "social area where different religions and confessions meet". Taking into consideration the case of Bosnia, according to various surveys, it seems that people possess a high level of confessional self-identification and a strong tendency to prove/ show and defend one's identity. In that respect it is assumed that the border is an area of both encounters and conflicts. Therefore, the author gives recommendations on how to relate to other confessions at the border believing that the outcomes of these relations could be positive if all the nations cherished and accepted the differences.

The paper on the development of sociology of religion in Bosnia and Herzegovina from 1991 to 2007 illustrates the author's findings on the changes in the research field, differences between sociology of religion and religious sociology, the position of sociologists of religion, the development of empirical research, publishing and educational activity in the region. Some advantages and difficulties sociologists of religion encounter when teaching university students are also pointed out.

The next paper concentrates on methodological problems in the sociological research of the Orthodox creed. The author outlines five levels of research of the Orthodox creed. It briefly reviews major methods and techniques used in sociological research of the Orthodox creed, including the use of reports, articles, polls and scales of attitudes, etc. Additionally, it gives guidelines for a successful researcher and proposes a number of insufficiently explored topics on Orthodox creed, which could serve as a basis for further research.

Professor Cvitković has already dealt with the issue of religion in the context of globalization in his previous work, but he addresses it once again offering some additional views in the paper Religion and Globalization. The process of globalization leads the author to revise the notions of universal religions, religious pluralism, and religious nationalism. He discusses cosmopolitan and fundamentalist form of religious globalization. The article raises a number of questions concerning the impact of globalization on religion and their outcomes. 
Another hypothesis that professor Cvitković is trying to prove is that the return of religion into the public sphere has occurred in post-socialist exYugoslav territories and not the return to the religion, as it may seem. The article discusses the reasons which could influence the return to religion and suggests one of the possible typologies of returnees to religion and converters. Additionally, it presents the characteristics of reconstructed religiousness. Drawing upon the results of previous research, the author observes that the changes in post-socialist period occurred at the level of public institutions, not at the level of individual believers.

Pilgrimage has been an important element of religious practice for a long time, which is why the last paper of the collection was dedicated to this social and religious phenomenon. Firstly, the article explains how the concept of pilgrimage is defined and treated in the holy books. Secondly, it offers a typology of pilgrimage based on two criteria: spatial importance and the place of pilgrimage. Pilgrimage is also explored as a social phenomenon, its economic aspects, its impact on strengthening religious identity, the code of conduct and dress code in the place of pilgrimage. In the end, a comparison between pilgrimage and religious tourism is made. The paper offers a wealth of concrete examples of religious practice of various religious communities in different parts of the world.

Encountering Others is a remarkable collection of papers that will be of great interest not only to sociologists of religion but to anyone interested in the way the church/religion influences people's lives. The author discusses a variety of current issues and draws some important conclusions based on thorough and unbiased examination. This collection could certainly serve as a starting point for young researchers and their future work in this field. 